\title{
Quality Assessment of Some Freshwater Resources Located in Bucharest and Surrounding Areas III. Case Study: Trophic Status Assessment of Mogosoaia, Herastrau and Pantelimon Lakes
}

\author{
VIOLETA MONICA RADU ${ }^{1,2}$, PETRA IONESCU1,2*, GYORGY DEAK ${ }^{1 *}$, ALEXANDRU ANTON IVANOV ${ }^{1}$, ELENA DIACU², \\ ANA MARIA ANGHEL ${ }^{1}$ \\ ${ }^{1}$ National Institute for Research and Development in Environmental Protection, 294 Spl. Independentei, 06003, Bucharest, \\ Romania \\ University Politehnica of Bucharest, Faculty of Applied Chemistry and Materials Science, 1-7 Polizu Str., 011061, Bucharest, \\ Romania
}

\begin{abstract}
The aim of this paper is the evaluation of the trophic status of three lakes riparian to the Colentina River, namely Mogosoaia, Herastrau, Pantelimon, as Part III of an extended study on evaluation of the freshwater resources quality in Bucharest and surrounding areas [1,2], supplementing the general quality assessment based on indices and indexes presented in Part I with a more in depth analysis of nutrient speciation and partitioning between water and upper sedimentary layers. Water and sediment samples were taken from the inlet and outlet areas of each lake in two sampling campaigns in July 2016 and September 2016. Some of the nutrient related water quality parameters presented in Part I of this series have been used here, together with the analysis of total nitrogen and total phosphorus content in sediments, to assess the general trophic state of the lakes and to highlight the relationships between the nitrogen and the phosphorus content from water and sediments. The studied lakes were found to be eutrophic, Mogosoaia and Pantelimon being in the mostadvanced state. A significant amount of nitrogen and phosphorus was detected in all sediments analysed, constituting a high accumulation of nutrients from anthropogenic activities. Actions to improve local sanitation infrastructure and to prevent anaerobic leakage of nutrients from sedimentary deposits are recommended.
\end{abstract}

Keywords: lakes, eutrophication, water quality, nutrients

Water is an important receptor of the environmental problems generated by various activities from the human society, being an essential ecological component for sustainable development. The main sources of the aquatic environment pollution are improper management of wastewaters, industrial effluents and agricultural activities [3-5].

Among the ecological problems of the aquatic environment, an important one is the eutrophication phenomenon, which represents a secondary pollution [6, 7]. The major cause of water eutrophication is the supplementation, beyond the water body equilibration capacity and often beyond permitted legal limits, of nutrients containing phosphorus and nitrogen. Their excess determines the abnormally increased production of algae and higher plants, leading to increased turbidity and lower dissolved oxygen concentrations, phenomena which are accompanied by the disappearance of aquatic fauna [8, 9]. This further intake of organic detritus leads to anoxic conditions in the sedimentary layers releasing even more nutrients stored there under oxic conditions [10]. It is generally accepted that the eutrophication of surface water bodies is a major problem of water quality because it affects both economic and social environments [11, 12].

Recent studies have identified climate change as a potential major contributor factor that may lead to accelerated eutrophication of rivers and lakes [13]. The synergistic contribution of climate change associated with anthropogenic activities has altered the transfer of nitrogen and phosphorus between environment compartments towards the aquatic ecosystems, leading to accumulations of pollutants in the closely intertwined biotic and abiotic phases of the aquatic ecosystems $[14,15]$.
In Bucharest, an essential part of the urban ecosystem are the lakes along the Colentina River, which occupy $3.25 \%$ of the city's surface, and are of particular importance in the protection against floods, recreational activities, improving the urban environment quality, fisheries and so on [16]. From upstream to downstream, Bucharest hosts the following lakes: Straulesti, Grivita, Baneasa, Herastrau, Floreasca, Tei, Plumbuita, Fundeni, Pantelimon, located in Bucharest and Buftea, Buciumeni, Mogosoaia, Chitila located in Ilfov County, with an total area of 1295 hectares $[16,17]$.

In the peripheral area of Bucharest, due to the urban expansion and development of residential areas, the water quality of the artificial lakes has decreased significantly. This process is largely underlined by the poor coverage of the public sewerage system. Therefore, a big part of the household wastewater is discharged directly or indirectly into the lakes along the Colentina River, contributing to the degradation of water quality and emergence of health problems [18]. Urban lakes are particularly exposed to a high risk of pollution, large amounts of pollutants lead to increased eutrophication, which affects the habitat of wild life and the quality of human life [19,20].

Part I in the series of study for quality assessment of some freshwater resources located in Bucharest and surrounding areas [1] presents the quality assessment for Mogosoaia, Herastrau and Pantelimon lakes by employed various multi-parametric indices and the class-based evaluation system [21] for water and sediment quality. Part II of the mentioned study [2] extends the quality evaluation on the Arges and Dambovita Rivers, components of the overall hydrographic region of the Colentina River on which the Mogosoaia, Herastrau and Pantelimon lakes are

\footnotetext{
*email: petraionescu2012@yahoo.ro; dkrcontrol@yahoo.com
} 
formed. PartIII of the study comes back to the Mogosoaia, Herastrau and Pantelimon lakes, with a more in-depth analysis of nutrient speciation and partitioning between water and upper sedimentary layers, in order to provide a more detailed view on the respective trophic states and the further eutrophication risks posed by nutrients accumulation in sedimentary deposits.

\section{Experimental part}

To characterize the eutrophication status of the lakes Mogosoaia, Herastrau, Pantelimon, two sampling sections were established for each lake, the inlet(SI) and the outlet of the lake (SII), the initial letter of the lake being assigned to each section as follows: for the Mogosoaia lake the sampling sections were SI-M and SII-M, for Herastrau lake: SI-H and SII-H and for Pantelimon lake: SI-P and SII-P (Fig. $1)$.

The water and sediment samples were taken from the inlet and outlet areas for each lake in two sampling campaigns (C I - J uly 2016 and C II -September 2016).

In order to assess the trophic status of the abovementioned lakes, for water samples the following indicators were determined: $\mathrm{pH}$, turbidity, dissolved oxygen
(DO), ammonium $\left(\mathrm{NH}_{4}-\mathrm{N}\right)$, nitrites $\left(\mathrm{NO}_{2}-\mathrm{N}\right)$, nitrates $\left(\mathrm{NO}_{3}-\right.$ $\mathrm{N})$, total nitrogen $(\mathrm{TN})$, orthophosphates $\left(\mathrm{PO}_{4}-\mathrm{P}\right)$ and total phosphorus (TP) for water samples and total nitrogen $(\mathrm{TN}<\mathrm{S}>$ ) and total phosphorus ( $\mathrm{TP}<\mathrm{s}>$ ) from the $<63 \mu \mathrm{m}$ granulometric fraction of the sediment samples (Table 1). Water samples were collected in polyethylene recipients $(3 \mathrm{~L})$ from approximately $30 \mathrm{~cm}$ under the water surface and were kept at $4^{\circ} \mathrm{C}$ during transport, according to the internal sampling procedure developed in accordance with the standards in force [22-25].

Sediment samples were collected in polyethylene recipients, previously washed with detergent and rinsed with distilled water, according to the internal sampling procedure developed in accordance with the standards in force and were analysed according to a standard method used for soil samples [26, 27]. The relationships between the nitrogen and the phosphorus content from water and sediment was assessed.

All reagents used for determining the indicators mentioned above were of analytical purity and their determinations were performed using the standardised methods of analysis.

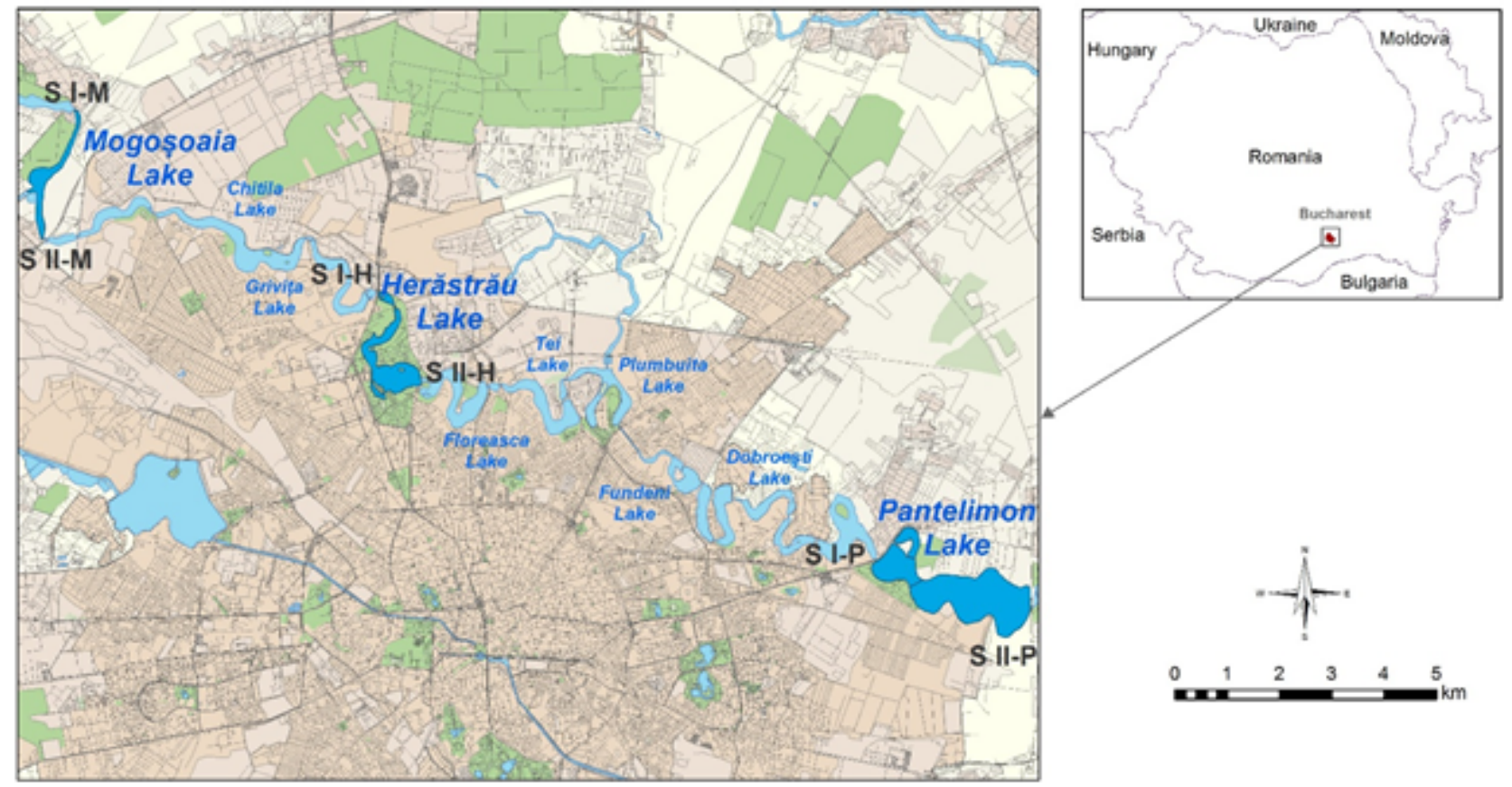

Fig. 1. The map of the study area with sampling sections [1]

Table 1

PARAMETERS MEASURED FOR WATER AND SEDIMENT SAMPLES, THEIR UNITS, ABBREVIATIONS USED AND ANALYTICAL METHODS

\begin{tabular}{|c|c|c|c|}
\hline Parameter & Units & Abbreviation & Analytical method \\
\hline $\mathrm{pH}$ & $\mathrm{pH}$ units & $\mathrm{pH}$ & Potentiometry \\
\hline Turbidity & NTU & turbidity & Turbidimetry \\
\hline Dissolved oxygen & $\mathrm{mgO}_{2} / \mathrm{L}$ & DO & \multirow[t]{3}{*}{ Titrimetry } \\
\hline Total nitrogen & $\mathrm{mgN} / \mathrm{L}$ & TN & \\
\hline Total nitrogen - sediment & $\mathrm{mgN} / \mathrm{kg}$ & TN(s) & \\
\hline Total phosphorus & $\mathrm{mgP/L}$ & TP & \multirow{6}{*}{$\begin{array}{c}\text { Molecular absorption } \\
\text { spectrometry }\end{array}$} \\
\hline Ammonium-nitrogen & $\mathrm{mgN} / \mathrm{L}$ & $\mathrm{NH}_{4}-\mathrm{N}$ & \\
\hline Nitrite-nitrogen & $\mathrm{mgN} / \mathrm{L}$ & $\mathrm{NO}_{2}-\mathrm{N}$ & \\
\hline Nitrate-nitrogen & $\mathrm{mgN} / \mathrm{L}$ & $\mathrm{NO}_{3}-\mathrm{N}$ & \\
\hline Orthophosphates & $\mathrm{mgP/L}$ & $\mathrm{PO}_{4}-\mathrm{P}$ & \\
\hline Total phosphorus - sediment & $\mathrm{mgP} / \mathrm{kg}$ & $\mathrm{TP}(\mathrm{s})$ & \\
\hline
\end{tabular}




\section{Results and discussions}

For a more accurate assessment of the trophic status of the monitored ecosystems, the evolution of the quality indicators values from both sampling campaigns was pursued. Thus, the pH diagram (Fig. 2) shows higher values recorded for the second campaign, rise which could be caused by combined anthropogenic influences with increased late-summer biomass production values which influence both the $\mathrm{CO}_{2}$ and the redox equilibriums in temperate lakes. Turbidity is a parameter that undergoes changes usually in direct correlation with local hydrodynamic conditions, but it is also indirectly influenced by the seasonal biological activity and other anthropogenic pressures related to residential density of nearby areas.

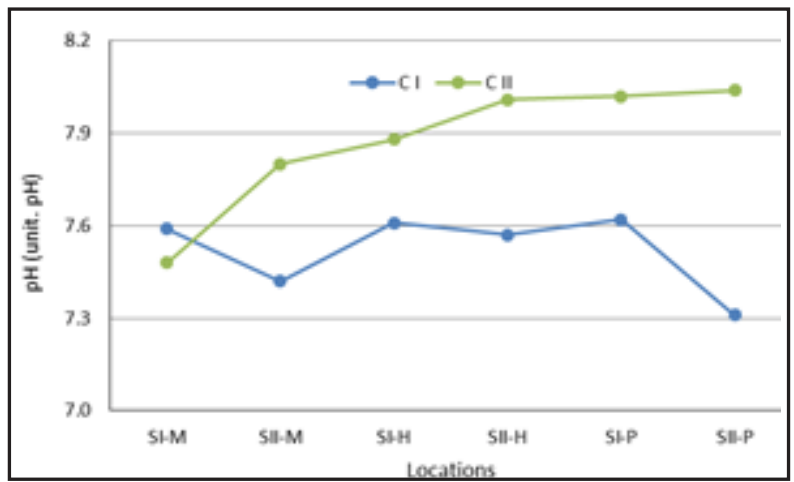

Fig. 2. $\mathrm{pH}$ variation in Mogosoaia (SI-M, SII-M points), Herastrau (SI-H, SII-H points) and Pantelimon (SI-P, SII-P points) lakes

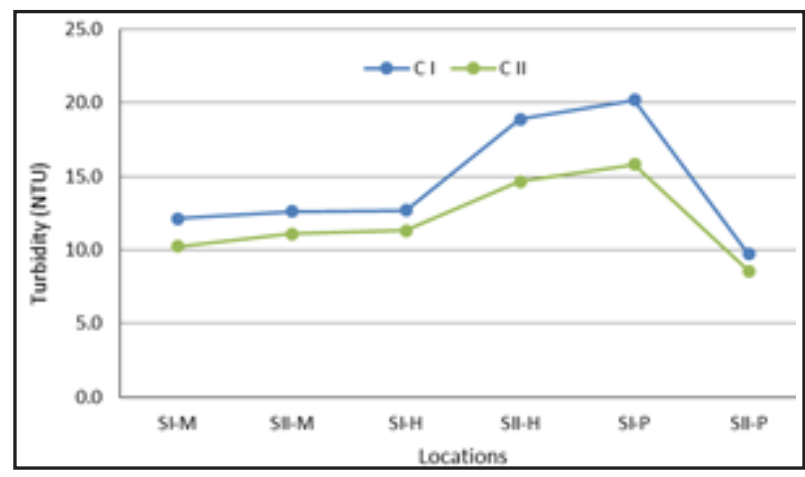

Fig. 3. Turbidity variation in Mogosoaia (SI-M, SII-M points), Herastrau (SI-H, SII-H points) and Pantelimon (SI-P, SII-P points) lakes

The nutrient levels in the water samples are presented in figure 4. Nutrients levels were found generally to be higher for Mogosoaia and Pantelimon Lakes. Orthophosphates values constituted about half of the total phosphorus content from the water samples whereas ammonium nitrogen was the major contributor in the nitrogen balance, accounting for about half of the value of the total nitrogen parameter, the rest being mostly organic nitrogen with relative low contributions from nitrites and nitrates.

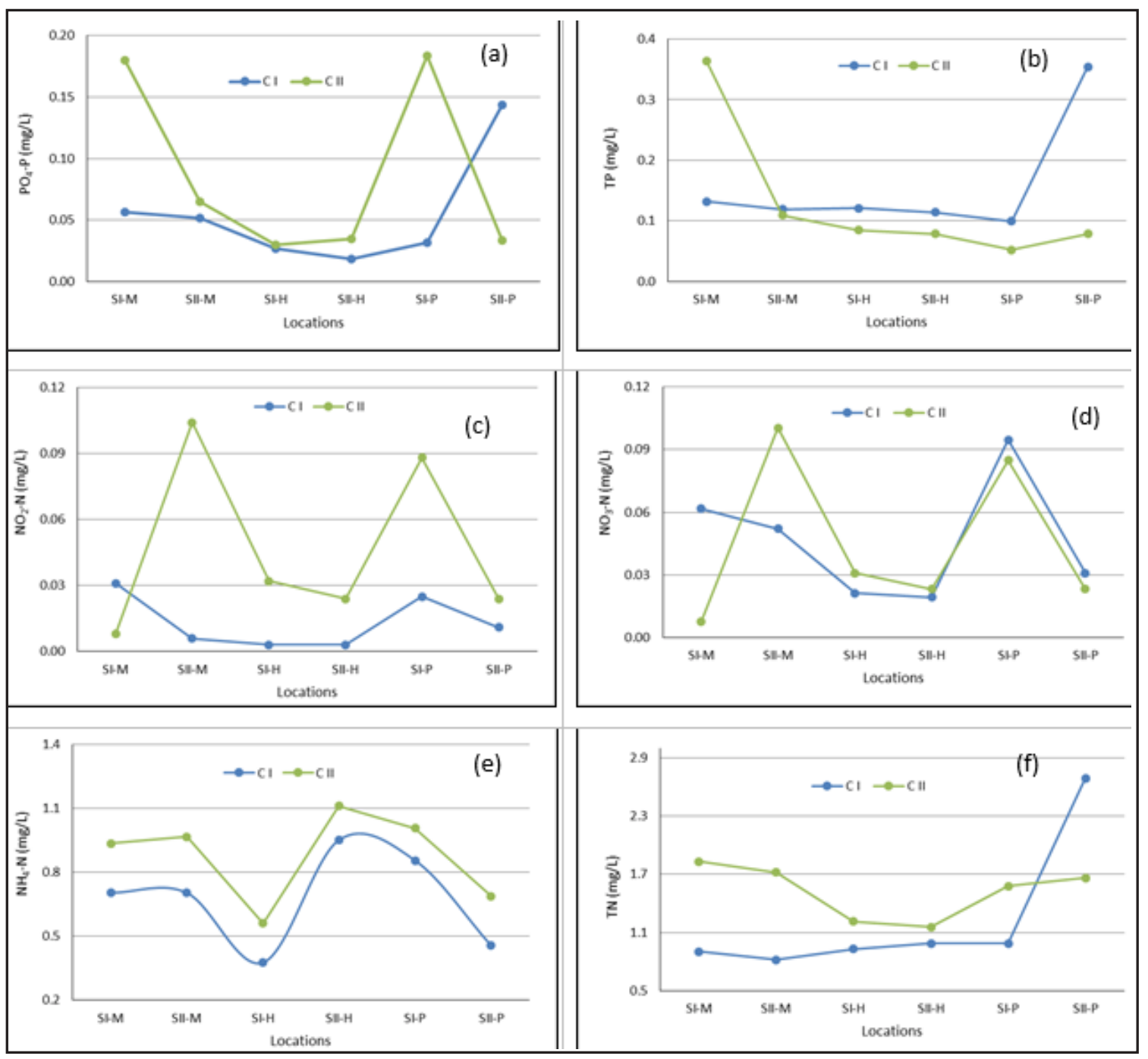

Fig. 4. Variation of nutrients in water of Mogosoaia (SI-M, SII-M points), Herastrau (SI-H, SII-H points) and Pantelimon (SI-P, SII-P points) lakes: (a) $\mathrm{PO}_{4}-\mathrm{P} ;$ (b) TP; (c) $\mathrm{NO}_{2}-\mathrm{N}$; (d) $\mathrm{NO}_{3}-\mathrm{N}$; (e) $\mathrm{NH}_{4}-\mathrm{N}$; (f) TN 

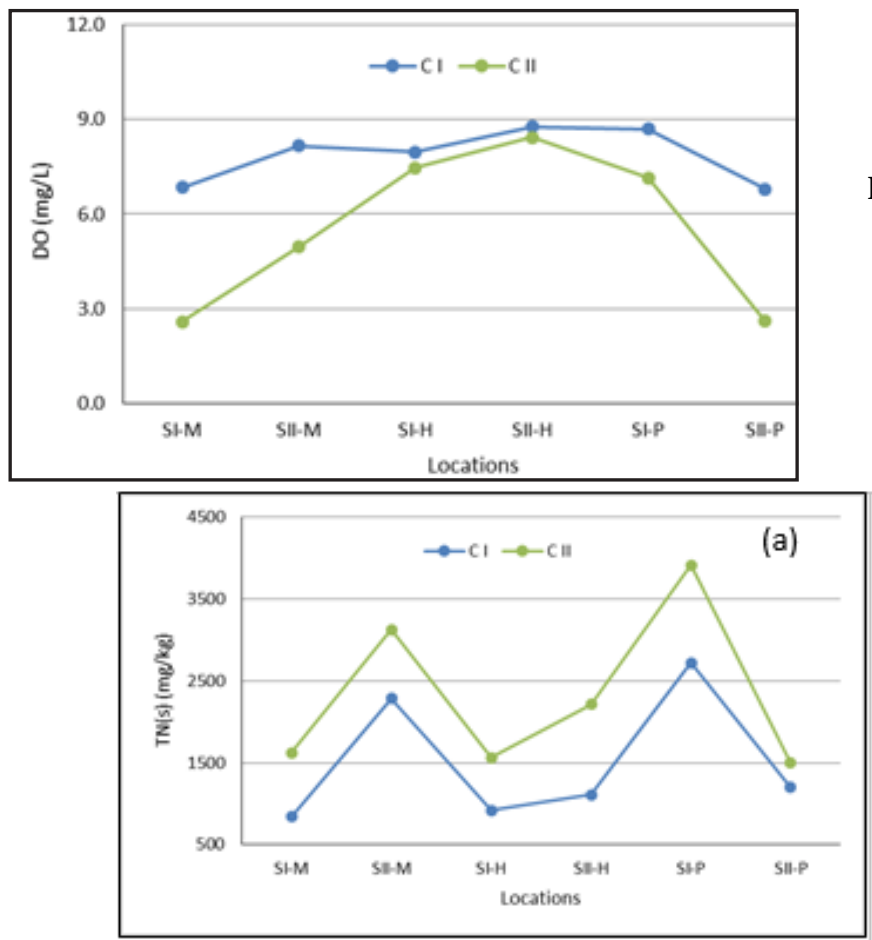

Fig. 6. Variation of nutrients in sediments of Mogosoaia (SI-M, SII-M points), Herastrau (SI-H, SII-H points) and Pantelimon (SI-P, SII-P points) lakes: (a) TN(s) and (b) TP(s)

On the other hand, nitrite concentrations exceeded the admitted levels enforced by the M.0. 161/2006 normative [21]. The large fraction of ammonium nitrogen usually is associated either with recent events of uncontrolled wastewater discharges or with longer periods rich with readily available organic matter and historical nutrients which overload the lakes biotic-abiotic equilibrium in the warm seasons, high ammonium values also being associated with low dissolved oxygen levels and even anoxic conditions. The elevated nitrite levels may be associated to either the partial oxidation of ammonium under low dissolved oxygen conditions or even to nitrate reduction processes under anoxic conditions.

The dissolved oxygen concentration in the water column plays an essential role in the biotic-abiotic equilibrium in lakes. Low levels of dissolved oxygen in the upper water layers caused by excessive flora development or high organic pollutant loads usually initiate a cascade of amplified adverse effects including a high mortality of aquatic fauna which further increase the organic load of the benthic area which cause the shift of the redox potential of the upper sedimentary layers leading to accelerated historical nutrients leaching in the water column resulting in an even more disproportionate development of the lake flora toward algal bloom events. In the limitrophe urban and sub-urban newly developing regions due to the lag in the implementation of adequate sewer networks and treatment facilities, the wastewater influx to the lakes is greater leading to environmental problems such as accelerated eutrophication phenomena present for years to come due to de formation of significant reserves of nutrients in the sedimentary layers during the early ecosystem natural compensation processes, mainly through increased biological productivity. Only when these processes exceed the natural equilibration capacity, the excess biomass leads to adverse changes decreasing the number of higher-order aquatic species and the instauration of typical eutrophic symptoms.

As seen in figure 5 , the dissolved oxygen in the upper water column is already low in the outer upstream and downstream lakes, namely Mogosoaia and Pantelimon

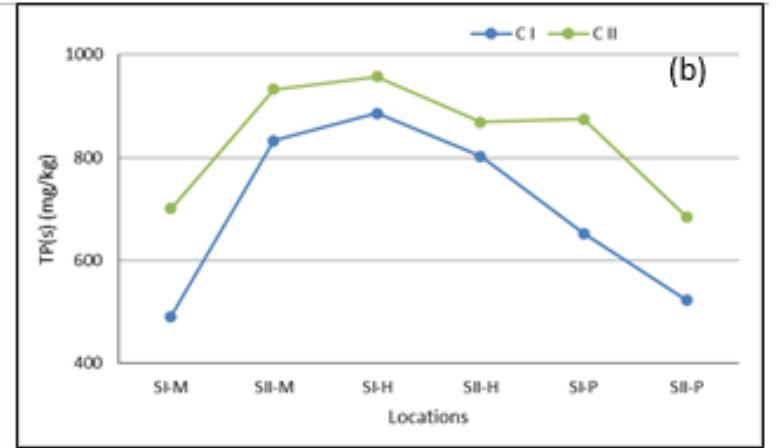

Fig. 5. DO variation in the Mogosoaia (SI-M, SII-M points), Herastrau (SI-H, SII-H points) and Pantelimon (SI-P, SII-P points) lakes

where the anthropogenic pressures are grater. As water transits the network of lakes, the natural compensation processes take effect leading to higher oxygen concentrations in the water column but also to the accumulation of greater levels of nutrients, mainly phosphorus, in the sedimentary layers (fig. 6). Conversely, due to the low oxygen levels in the outer-lakes, the historic sedimentary nutrients leaching process in the water column is dominant, leading to lower nutrients levels in the respective sediment samples.

The nitrogen-based nutrients solubility from sediment is less dependent on the benthic redox potential than the solubility of phosphorus-based nutrients. Under oxic conditions, phosphorus is retained in sediments as less soluble inorganic compounds (such as those with iron, aluminium and calcium ions) and as organic compounds from the non-degraded organic matter. Due to the high solubility of inorganic nitrogen salts (nitrates, nitrites and ammonium salts), the nitrogen-based nutrients in sediments are mostly found as organic compounds from the non-degraded organic matter.

Nevertheless, a significant accumulation of nitrogen and phosphorus in the sediments is evident from Figure 6, most probably caused by years of excess nutrient inputs, the main source of these being the anthropogenic activities, such as agriculture, uncontrolled waste disposal, wastewater discharge, etc..

\section{Conclusions}

The study on trophic status assessment of Mogosoaia, Herastrau and Pantelimon lakes has shown a higher level of nutrients than permitted limit by law in waters of Mogosoaia and Pantelimon lakes for the studied period; moreover, for all three mentioned lakes, a significant accumulation of nitrogen and phosphorus was detected in the sediment layers formed with significant inputs from anthropogenic activities such as agriculture and uncontrolled waste disposal. These findings suggest the need for more important actions that can be carried out through two main objectives. First, the release of anthropogenic nutrients from inappropriate sewage 
systems and uncontrolled waste disposal through the improvement of local sanitation infrastructure must be prevented and secondly, measures must be taken to prevent anaerobic leakage of nutrients from sedimentary deposits by ensuring adequate aeration throughout the year of the water column and upper sedimentary layers. These objectives can be achieved through the implementation of the Environmental Action Plan and the Local Sustainable Development Strategy, focusing on uncontrolled waste prevention and the implementation of appropriate sewerage systems.

Acknowledgements: This work used data obtained through the MEVAS $48 N / 2016$, project PN 16040104. The authors would like to thank the management and employees of National Institute for Research and Development in Environmental Protection for their valuable assistance and suggestions. Violeta-Monica Radu's contribution was partially financed by the Operational Programme Human Capital of the Ministry of European Funds through the Financial Agreement 51668/09.07.2019, SMIS code 124705.

\section{References}

1. IONESCU, P., RADU, V.-M., DEAK, Gy., DIACU, E., MARCU E., CIOBOTARU I.-E., Rev.Chim. (Bucharest), 70, no. 8, 2019,p. 2889

2. IONESCU, P., IVANOV, A.A., RADU, V.-M., DEAK, Gy., DIACU, E., MARCU, E., ANGHEL, A., Rev.Chim. (Bucharest), 70, no. 10, 2019, p. 3638

3. DEAK, Gy., DAESCU, V., HOLBAN, E., MARINESCU, P., TANASE, G., CSERGO, R., DAESCU, A.I., GAMAN, S., J Environ Prot Ecol., 16, 2015, p. 304.

4. DAESCU, A.I., HOLBAN, E., BOBOC, M.G., RAISCHI, M.C., MATEI, M., ILIE, M., DEAK, GY., DAESCU, V., J Environ Prot Ecol., 18, no. 1, 2017, p. 304

5. PAVELESCU, G., GHERVASE, L., IOJA, C.I., SAVASTRU, D., Lakes, reservoirs and ponds, $\mathbf{8}$, no. 1, 2014, p. 42.

6. STACHELEK, J., FORD, C., KINCAID, D., KING, K., MILLER, H., NAGELKIRK, R., Earth Syst. Sci. Data, 10, 2018, p. 81.

7. STEFAN, D.S., NEACSU, N., PINCOVSCHI, I., STEFAN, M., Rev.Chim. (Bucharest), 68, no. 1, 2017, p. 60.

8. CIRTINA, D., CAPATINA, C., Rev. Chim. (Bucharest), 67, no. 12, 2016, p. 2429.

9. CIOBOTARU, I.E., MARCU, E., CIMPOERU, C., SAVIN, I., IVANOV, A.A., AES Bioflux, 9, no. 1, 2017, p. 6.
10. WANG, S., JIN, X., BU, Q., JIAO, L., WU, F., Colloids and Surfaces A: Physicochemical and Engineering Aspects, 316, 2008, p. 245.

11. MOLDOVEANU, M., Ecoterra - Journal of Environmental Research and Protection, 14, no. 3, 2017, p. 28.

12. BENCIU, F., ENCIU, M., BUJ OR, L., BOGAN, E., PUIA, O.-A., GABOR, S., International J ournal of Academic Research in Environment and Geography, 4, no. 1, 2017, p. 17.

13. PANDHAL, J., CHOON, W.L., KAPOORE, R.V., RUSSO, D.A., HANOTU, J., GRANT WILSON, I.A., DESAI, P., BAILEY, M., ZIMMERMAN, W.J., FERGUSON, A.S., Biology, 7, no. 4, 2018, p. 1.

14. MATEI, M., LASLO, L., CIOBOTARU, N., MUSAT, C., BOBOC, M., RAISCHI, M., DEAK, Gy., International J ournal of Environmental Science, 1, 2016, p. 265.

15. ARVOLA, L., SALONEN, K., KESKITALO, J., TULONEN, T., JARVINEN, M., HUOTARI, J., Boreal Environment Research, 19, 2014, p. 83.

16. STÃNESCU, S.V., Ecoterra - J ournal of Environmental Research and Protection, 27, 2011, p. 53. Romanian.

17. BARBULESCU, C.O., CODESCU, V.G., J ournal of Young Scientist, III, 2015, p. 23.

18. IONESCU, P., MARCU, E., RADU, V.-M., CIOBOTARU, I.E., TOCIU C., Ecoterra - J ournal of Environmental Research and Protection, 14, 2017, p. 19.

19. CARSTEA, E.M., IOJA, C.I., SAVASTRU, R., GAVRILIDIS, A., Romanian Reports in Physics, 65, no. 3, 2013, p. 1092.

20. TOROK, L., TOROK, Z., CARSTEA, E.M., SAVASTRU, D., Water Environment Research, 89, no. 1, 2017, p. 86.

21.***Ministerial Order 161/16.02.2006 on the approval of the Normative regarding the classification of the quality of surface water in order to establish the ecological status of water bodies.

22. *** ISO 5667-1:2007, Water quality. Sampling. Part 1: Guidance on the design of sampling programmes and sampling techniques.

23. ***EN ISO 5667-3:2013, Water quality. Sampling. Part 3: Preservation and handling of water samples.

24. ***ISO 5667-6:2017, Water quality. Sampling. Part 6: Guidance on sampling of rivers and streams.

25. *** ISO 5667-12:2017, Water quality. Sampling. Part 12: Guidance on sampling of bottom sediments from rivers, lakes and estuarine areas. 26. *** ISO 14255:2000, Soil quality. Determination of nitrite nitrogen, ammonium nitrogen and total soluble nitrogen in air-dry soils using calcium chloride solution as extractant. Romanian.

27. ***ISO 5667-15:2010, Water quality. Sampling. Part 15: Guidance on the preservation and handling of sludge and sediment samples.

Manuscript received: 12.03 .2019 